\title{
Analisis Pelaksanaan Peran, Fungsi dan Wewenang Governing Body di Rumah Sakit Islam NU Demak
}

\author{
Rudiansyah*, Sarsintorini Putra**, Sudiro** \\ *Sekolah Tinggi Ilmu Kesehatan Kapuas Raya Sintang, Kalimantan Barat, **Staf Pengajar Program \\ Magister Ilmu Kesehatan Masyarakat Universitas Diponegoro \\ Email:zaidummi@gmail.com
}

\begin{abstract}
Hospital health services have a high level of complexity and are prone to conflicts both inside and outside the hospital. The implementation of quality management is still a lot of obstacles faced evidenced by many hospital staff who do not know about quality management, frequent conflicts and lack of clarity of coordination, communication and information channels. The purpose of this research is to analyze the implementation of the role, function and authority of governing body, director, medical committee and nursing committee, quality management implementation, quality leadership and hospital barrier in order to improve quality management of NU Demak Islamic Hospital. This research design using descriptive method with qualitative approach. The main informants were the governing body, the director, the medical committee and the nursing committee and the triangulation informant were the executing physician, the nurse and the chairman of the quality team. Data were collected by in-depth interview techniques. Processing and data analysis using content analysis. The results show the role and function governing body has been implemented but the authority has not been implemented optimally. The role and authority of the director have been
\end{abstract}

implemented but the function has not been implemented optimally. The role and function of the medical committee has been implemented but the authority has not been implemented optimally. The role and function of the nursing committee has not been implemented optimally but the authority has been implemented. Quality planning has been implemented, but quality control and improvement has not been implemented optimally. Building vision, inspiring processes, mobilizing human resources and becoming a model has been implemented. It is recommended to allocate budgets for the training of the ex-house training, to make guidelines for recording and reporting, to make guidance on performance evaluation of officers, to create a checklist of performance evaluation and to make an assessment of internal satisfaction

Keywords : Implementation Analysis; Governing Body; Quality Management

\section{PENDAHULUAN}

Dalam pelaksanaan manajemen mutu masih ditemukan adanya kendala di Rumah Sakit Islam NU Demak. Ketidaktahuan staf rumah sakit akan pentingnya manajemen mutu, ketidakjelasan alur koordinasi komunikasi 
dan informasi antara governing body, direktur dan komite medik. Pihak manajemen rumah sakit dengan staf sering terjadi konflik dan masih ditemukan adanya pelanggaran terhadap peraturan yang ada, serta belum ada pedoman standar sarana dan prasarana yang terstandar.

Sosialisasi manajemen mutu yang belum dilakukan dengan baik, dukungan terhadap pelaksanaan kebijakan manajemen mutu dari pihak yang terkait masih kurang. Hal tersebut ditandai dengan kurangnya pelatihan dalam peningkatan keterampilan staf, pencatatan dan pelaporan masih belum tumbuh dengan baik, proses pengawasan dan pembinaan masih kurang, proses kredensial khususnya keperawatan masih melalui sistem pemutihan, peraturan yang ada sering tumpang tindih.

Organisasi rumah sakit mempunyai bentuk yang unik, yang berbeda dengan organisasi lain pada umumnya. Rumah sakit mempunyai kekhususan yang lahir dari adanya hubungan yang terjadi antara Medical Staff (kelompok dokter) dan Administrator atau Chief Executive Officer (manajemen) serta Governing Body sebagai pemilik. Dokter dalam kaitannya sebagai profesional tidak tepat jika ditempatkan secara hirarki piramidal dalam struktur organisasi rumah sakit, namun mereka mempunyai struktur tersendiri dalam Medical Staff Organization.

Secara klasik di Amerika, struktur organisasi rumah sakit memang khas sebagai splitting organization dengan tiga pusat kekuasaan atau kekuatan yaitu Governing Body sebagai pemilik, Administrator dan Medical Staff yang langsung mendapat otoritasnya dari Governing Body. Oleh karena itu rumah sakit merupakan sebuah organisasi yang memiliki tingkat kompleksitas tinggi akibat adanya hubungan-hubungan tersebut, dimana otoritas formal yang direpresentasikan oleh Administrator atau Chief Executive Officer (manajemen) harus mengakomodasi otoritas keilmuan dan keahlian yang dimiliki oleh kelompok dokter, dimana secara historis mereka memegang peran yang sangat besar dalam organisasi rumah sakit dan mendapatkan otoritasnya dari Governing Body. Untuk menjaga agar hubungan ketiganya berjalan harmonis, maka diatur dalam Hospital by laws masing-masing rumah sakit yang pada prinsipnya menetapkan dan mengatur tentang tugas, kewenangan, hubungan fungsional dan hubungan tanggung jawab antara Governing Body, Administrator dan Medical Staff di rumah sakit.

Tata kelola rumah sakit dan tata kelola klinis yang baik dalam peningkatan manajemen mutu merupakan tanggung jawab dari seluruh komponen yang ada baik dari pihak pemilik (governing body), manajemen (direktur), komite medik dan komite keperawatan serta yang lainya. Semua komponen tersebut harus melakukan peran, fungsi dan wewenang yang baik sesuai dengan peraturan yag ada dan ketentuan yang berlaku. Berdasarkan uraian tersebut, maka peneliti tertarik untuk melakukan penelitian lebih lanjut mengenai pelaksanaan peran, fungsi dan wewenang governing body, direktur, komite medik dan komite keperawatan serta proses pelaksanaan manajemen mutu dan proses pelaksanaan kepemimpinan mutu dalam upaya peningkatan manajemen mutu di Rumah Sakit Islam NU Demak

\section{METODE PENELITIAN}

Penelitian ini menggunakan metode deskriptif dengan pendekatan kualitatif. 
Data primer dikumpulkan dengan melakukan wawancara mendalam (indepth interview) menggunakan pedoman wawancara kepada informan terkait informasi mengenai peran, fungsi dan wewenang governing body, direktur, komite medik dan komite keperawatan dalam upaya peningkatan manajemen mutu, proses pelaksanaan manajemen mutu dan kepemimpinan mutu di Rumah Sakit Islam NU Demak.

\section{HASIL PENELITIAN}

\section{Peran Governing Body di Rumah Sakit Islam NU Demak}

Peran governing body dalam menetapkan visi dan misi rumah sakit, pengawasan terhadap mutu pelayanan rumah sakit, mengawasi keterjangkauan pelayanan di rumah sakit, menetapkan cara untuk meningkatkan peran masyarakat dan melakukan integrasi dan koordinasi dengan pihak yang terkait di rumah sakit sudah dilakukan. Hal ini seperti yang diungkapkan oleh governing body.

"Ya mas untuk membuat visi dan misi rumah sakit kita melalui tahapan yang cukup panjang kita bermusyawarah dengan seluruh anggota yayasan. Kemudian dirumuskan visi dan misi lalu kita tetapkan dan disahkan sebagai visi dan misi di $R S$..........(Al)

Peran governing body sudah dilaksanakan untuk mendukung manajemen mutu yang ada di Rumah Sakit Islam NU Demak. Peran Governing Body akan menjadi penyangga atau penghubung yang memperjuangkan kepentingan rumah sakit kepada pihak-pihak luar termasuk pemerintah, sehingga rumah sakit benarbenar mendapatkan dukungan masyarakat dan bertanggung jawab terhadap kegiatan- kegiatan asuhan klinik terhadap pasien

\section{Fungsi Governing Body di Rumah Sakit Islam NU Demak}

Fungsi governing body diantaranya adalah menetapkan perencanaan jangka panjang serta tujuan organisasi, menyetujui anggaran tahunan, mengawasi keuangan sesuai dengan perencanaan dan anggaran, sudah dilakukan. Seperti yang diungkapkan oleh informan :

“...Ya kami sudah membuatkan perencanaan dan tujuan rumah sakit mas....kami membuat perencanaan ini dengan melibatkan seluruh komponen-komponen yang ada di rumah sakit...baik itu pihak direksi, komite medik dan komite keparawatan dan lainnya.... Direktur dan pihak direksi membuat perencanaan program dan anggaran tahunan kemudian diajukan kepada yayasan dan melakukan koreksi terkait dengan prioritasnya....(Al)

Fungsi governing body telah dilaksanakan untuk mendukung manajemen mutu yang ada di Rumah Sakit Islam NU Demak.

\section{Wewenang Governing Body di Rumah Sakit Islam NU Demak}

Wewenang governing body dalam peningkatan kompetensi melalui pelatihan untuk petugas medis dan perawat yang bekerja di pelayanan masih belum dilakukan. Hal ini seperti disampaikan oleh informan:

“........Tentu kami harus mendapat usulan dulu
dari pihak direktur dan selanjutnya kami
mempertimbangkan dari beberapa hal mulai
dari SDM yang ada, dana, waktu dan kebutuhan
mas....jika kita memilki semuanya dengan cukup
maka kami sangat mendukung untuk
peningkatan kompetensi baik melalui pelatihan
dan pendidikan ataupun pengadaan sarana dan
prasarana....(Al)


“....Ya keputusan itu terserah yayasan..dengan pertimbangan mulai dari lama kerja, kebutuhan, dana waktu dan lainnya..untuk pengembangan kompetensi dengan cara mengikuti seminar atau peningkatan lainnya masih belum banyak dilakukan karena banyak yang tidak di setujui oleh yayasan...(B2)

Wewenang governing body belum dilaksanakan secara optimal untuk mendukung dari manajemen mutu yang ada di Rumah Sakit Islam NU Demak karena masih ada beberapa hal terkait dengan peningkatan kompetensi melalui pelatihan masih kurang dilakukan untuk petugas medis dan perawat yang bekerja di bagian pelayanan.

\section{Peran Direktur di Rumah Sakit Islam NU Demak}

Peran direktur dalam membuat usulan tentang tujuan rumah sakit, cara menjalankan kebijakan, SPO dan peraturan lain yang telah ditetapkan, cara menyusun rencana kerja dan anggaran tahunan rumah sakit, proses koordinasi pelaksanaan tugas dan fungsi unsur organisasi, proses penetapan kebijakan penyelenggaraan Rumah Sakit sesuai dengan kewenangannya dan melakukan pembinaan, pengawasan, dan pengendalian sudah dilakukan semuanya. Hal ini seperti diungkapkan oleh direktur.

“....Cara kami menjalankan kebijakan yang ada
yaitu kami merancang program kerja, anggaran,
target waktu dan tenaga yang melaksanakan
program tersebut....untuk pelaksanaan dari SPO
ya kami sesuaikan dengan tindakan atau
pelayanan yang ada....(A2)
“....Komite medik membuat SPO dan aturan
lainnya dan disahkan oleh direktur...(B1)

Peran direktur sudah dilaksanakan untuk mendukung manajemen mutu yang ada di Rumah Sakit Islam NU Demak

\section{Fungsi Direktur di Rumah Sakit Islam NU Demak}

Fungsi direktur terkait sistem pencatatan dan pelaporan belum dilakukan. Hal ini seperti diungkapkan oleh informan

"Ya setiap morning report itu ada notulen dan ada laporannya. Pencatatan dan pelaporan sudah dilakukan namun masih belum intensif. Takut lapor tapi sudah didukung dan sudah jalan, budaya pelaporan itu masih belum tumbuh dengan baik...(Al)

"Ya direktur sudah melakukan pembinaan dintaranya melalui rapat koordinasi, rapat pimpinan dan lainnya, menegur langsung jika ditemui kesalahan, melaui WA dan lainnya....dan yang masih kurang yaitu budaya pelaporan dan direktur masih belum mengawasi dengan baik hal ini... (B1)

Fungsi direktur belum dilaksanakan secara optimal untuk mendukung dari manajemen mutu yang ada di Rumah Sakit Islam NU Demak karena masih ada yang perlu perbaikan yaitu mengenai sistem pencatatan, dan pelaporan yang seharusnya pencatatan dan pelaporan itu harus menjadi budaya untuk setiap kegiatan yang ada demi mendukung tercapainya tujuan dari rumah sakit tersebut.

\section{Wewenang Direktur di Rumah Sakit Islam NU Demak}

Terkait dengan wewenang direktur yang dilakukan meliputi membuat kebijakan operasional dan menetapkan berbagai peraturan yang belum diatur dalam hospital by law, mengusulkan rencana kerja, anggaran tahunan dan pengembangan rumah sakit dan cara mengendalikan penyelenggaraan rumah sakit agar tercapai target sudah dilakukan. Seperti dijelaskan oleh informan. 
“....Proses penyusunan anggaran kita mulai dari mengumpulkan pihak direksi dan kita meminta masukan dan program yang sesuai dengan kebutuhan di setiap bagian kemudian kita membuat rincian pembiayaan lalu kita ajukan kepada yayasan...(Al)

Wewenang direktur sudah dilaksanakan untuk mendukung manajemen mutu yang ada di Rumah Sakit Islam NU Demak

\section{Peran Komite Medik di Rumah Sakit Islam NU Demak}

Peran yang dilakukan oleh komite medik meliputi cara menyelenggara tata kelola klinis (clinical governance) yang baik dan proses menjaga profesionalisme staf medis melalui mekanisme kredensial, penjagaan mutu serta pemiliharaan etika dan disiplin profesi sudah dilakukan. Hal ini seperti diungkapkan oleh komite medik.

\footnotetext{
"Ya dengan pembinaan dan pengawasan dan pemanggilan terhadap yang tersangkut dengan masalah etik dan disiplin tersebut....membuat aturan dan SPO yang baik untuk setiap kegiatan...serta up date keterampilan dan tingkat pendidikan mas....(Al)

"Yang saya ketahui, ya komite medik malakukan pembinaan dan pengawasan dan membuat SPO...(BI)
}

Peran komite medik sudah dilaksanakan untuk meningkatkan manajemen mutu di Rumah Sakit Islam NU Demak

\section{Fungsi Komite Medik di Rumah Sakit Islam NU Demak}

Fungsi komite medik dalam kredensial bagi seluruh tenaga medis dijawab dengan baik oleh informan bahwa kredensial untuk dokter di Rumah Sakit Islam NU Demak sudah dilakukan. Hal ini seperti diungkapkan oleh informan.

“.....Ya sudah mas....(A3)

“....Ya kami sudah mendapatkan kredensial...(B1)

Fungsi komite medik sudah dilaksanakan untuk mendukung dari manajemen mutu yang ada di Rumah Sakit Islam NU Demak

\section{Wewenang Komite Medik di Rumah Sakit Islam NU Demak}

Wewenang komite medik dalam memberikan rekomendasi pendidikan medis dijawab informan bahwa belum ada rekomendasi untuk proses pendidikan kepada dokter untuk melanjutkan jenjang pendidikan ke tingkat spesialis. Sesuai dengan yang diungkapkan oleh infroman.

"Ya kami belum ada merekomendasi untuk
sekolah bagi para dokter untuk spesialis karena
dari pimpinan belum merestui mas...(A3)
"Belum ada rekomendasi pendidikan dari komite
medis mas...tidak tau kenapa...(B1)

Wewenang komite medik belum dilaksanakan secara optimal untuk mendukung manajemen mutu yang ada di Rumah Sakit Islam NU Demak karena seharusnya rekomendasi untuk melakukan melanjutkan jenjang pendidikan spesialis telah diberikan dan dimasukkan dalam perencanaan anggaran di Rumah Sakit Islam NU Demak.

\section{Peran Komite Keperawatan di Rumah Sakit Islam NU Demak}

Peran komite keperawatan tentang cara menyelenggara tata kelola keperawatan yang baik agar mutu pelayanan keperawatan dan keselamatan pasien lebih terjamin dan terlindungi 
dijawab oleh informan bahwa komite keperawatan masih belum melakukan tata kelola keperawatan dengan baik dengan alasan karena komite keperawatan baru terbentuk dan masih belum ada perencanaannya. Hal ini sesuai dengan ungkapan komite keperawatan.

“......Belum ada kami pak....karena masih baru ....Itu yang menjadi PR buat kita pak ya, kita punya angan-angan seperti itu tapi karena tenaga waktu dan SDM nya yang kurang jadi ya mutu kita hanya bisa mengevaluasi setiap 6 bulan sekali. Dan untuk pengembangan seperti apa kedepannya ya kita masih belum ada perencanaannya...(A4)

“....Ya saya belum melihat ada perubahan mas dari dulu dan memang komite keperawatan baru dibuat sih di RSI ini...(B2)

Peran komite keperawatan belum dilaksanakan secara optimal untuk mendukung manajemen mutu yang ada di Rumah Sakit Islam NU Demak karena masih ada beberapa hal yang harus dilakukan yaitu melakukan tata kelola keperawatan dengan baik dan memberikan pelatihan untuk meningkatkan keterampilan kepada tenaga perawat yang bekerja di pelayanan kesehatan

\section{Fungsi Komite Keperawatan di Rumah Sakit Islam NU Demak}

Fungsi komite keperawatan dalam upaya menjaga disiplin, etika, dan perilaku profesi perawat dijawab dengan baik oleh informan bahwa belum ada program yang dibuat untuk menjaga disiplin, etika dan perilaku. Hal ini seperti diungkapkan oleh informan

"....Secara terprogram dari komite keperawatan belum ada mas tetapi jika terjadi masalah yang menyangkut etika atau lainnya maka akan kita panggil secara langsung yang bersangkutan untuk dikonfirmasi atau diminta pertanggung jawabannya....(A4)

“....Saya belum melihat hal yang spesifik sudah dilakukan oleh komite keperawatan mas...tetapi jika ada masalah biasanya orang yang bersangkutan akan dipanggil sih...(B2

Fungsi komite keperawatan belum dilaksanakan secara optimal untuk mendukung manajemen mutu yang ada di Rumah Sakit Islam NU Demak karena perlu ada perbaikan terhadap beberapa hal yaitu upaya untuk kredensial dan rekredensial dan tindakan untuk menjaga disiplin, etika, dan perilaku profesi lebih diperhatikan lagi dan prosesnya harus terprogram dan terencana.

\section{Wewenang Komite Keperawatan di Rumah Sakit Islam NU Demak}

Wewenang komite keperawatan dalam proses memberikan rekomendasi rincian kewenangan keperawatan dijawab informan bahwa perawat mendaftarkan diri kepada tim kredensial keperawatan, lalu akan diadakan tes kemudian hasil tes tersebut akan menjadi rekomendasi dari tim kredensial kepada direktur dan selanjutnya direktur yang menerbitkan kewenangan keperawatan. Sesuai dengan yang diungkapkan oleh informan.

“...Ya prosesnya gini mas...perawat mendaftarkan diri kepada tim kredensial keperawatan, lalu akan diadakan tes kemudian akan keluar rekomendasi dari tim kredensial yang diberikan kepada direktur dan selanjutnya direktur yang menerbitkan kewenangan keperawatan mas....(A4)

“....Ya sudah mas...kan nanti rekomendasi itu akan menjadi bahan bagi direktur untuk menerbitkan keweanangan keperawatan...(B2)

Wewenang komite keperawatan sudah dilaksanakan untuk mendukung dari 
manajemen mutu yang ada di Rumah Sakit Islam NU Demak

\section{Perencanaan Mutu di Rumah Sakit Islam NU Demak}

Perencanaan mutu yang meliputi cara pemenuhan kebutuhan pelanggan atau konsumen, menentukan market segment pelayanan, proses mengembangkan karakteristik pelayanan dan cara mengembangkan proses yang mendukung pelayanan sudah dilakukan. Hal sesuai dengan yang diungkapkan oleh informan.

“......Ya kami berusaha untuk memberikan
pelayanan yang terbaik kapada pelanggan kami di
RSI NU ini, dibuktikan dengan kami berusaha
meningkatkan mutu layanan, menyiapkan fasilitas
pelayanan, tenaga kerja baik dokter, perawat dan
lainnya yang profesional dan mengembangkan
bangunan, ruangan pelayanan demi untuk
penambahan jumlah tempat perawatan
mas......(A2)

\section{Perencanaan mutu telah dilaksanakan untuk mendukung manajemen mutu yang ada di Rumah Sakit Islam NU Demak.}

\section{Pengendalian mutu di Rumah Sakit Islam NU Demak}

Pengendalian mutu meliputi beberapa hal yaitu mengevaluasi pelayanan, cara membandingkan antara performa aktual pelayanan dan target, tindakan lanjut jika terdapat perbedaan/penyimpangan.

Terkait membandingkan antara performa aktual pelayanan dan target dijawab oleh sebagian informan bahwa setiap akhir program akan ada evaluasi akhir dari tiap-tiap bagian dan oleh pimpinan, tetapi untuk bagian komite keperawatan belum melakukan perbandiangan antara performa aktual dengan target. Seperti yang diungkap oleh informan.

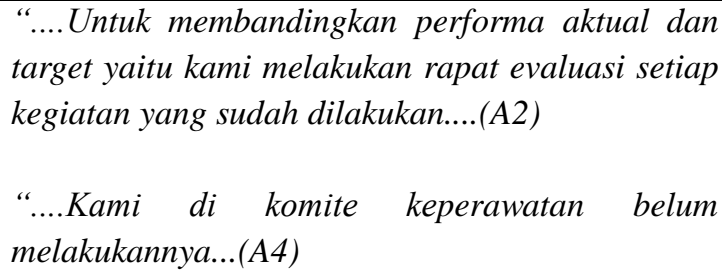

\begin{tabular}{cccc}
\multicolumn{2}{c}{ Pengendalian } & mutu belum \\
dilaksanakan secara & optimal & untuk
\end{tabular} mendukung dari manajemen mutu yang ada di Rumah Sakit Islam NU Demak karena ada beberapa hal yang perlu diperbaiki yaitu di bagian komite keperawatan yaitu harus melakukan perbandingan antara performa aktual dengan target dan terkait dengan pelatihan untuk meningkatkan keterampilan tenaga yang ada di rumah sakit masih kurang diberikan di Rumah Sakit Islam NU Demak.

\section{Perningkatan mutu di Rumah Sakit Islam NU Demak}

Peningkatan mutu dalam peningkatan manajemen mutu di Rumah Sakit Islam NU Demak meliputi beberapa hal yaitu infrastruktur yang sudah dibuat untuk peningkatan mutu rumah sakit, membentuk tim kerja, memberikan pendidikan dan pelatihan-pelatihan yang relevan dan cara penanggulangan masalah yang terjadi

Terkait pembentukan tim kerja informan ada perbedaan persepsi tentang tim kerja. Informan utama menjawab sudah ada tim kerja sedangkan informan triangulasi menjawab bahwa belum adanya tim kerja karena tenaga yang tersedia masih kurang perbedaan ini terjadi karena perbedaan memahami tim kerja tersebut. 
Hal ini seperti diungkap oleh informan.

“....Ya sudah ada tim kerja di RS...(Al)

“....Sudah ada....(A2)

“...Belum ada tim kerja khusus mas, karena masih kekurangan tenaga...(A3)

Peningkatan mutu belum

dilaksanakan secara optimal untuk mendukung dari manajemen mutu yang ada di Rumah Sakit Islam NU Demak karena ada beberapa hal yang perlu diperbaiki yaitu membentuk tim kerja dan menambah tenaga kerja baru baik dokter maupun perawat serta memberikan pelatihan yang cukup kepada karyawan untuk peningkatan pengetahuan dan keterampilan dari karyawan yang ada di Rumah Sakit Islam NU Demak.

\section{Membangun Visi di Rumah Sakit Islam NU Demak}

Membangun visi yang dilakukan meliputi membuat visi, mengkomunikasikan, membangun jejaring dan mempersonafikasikan visi dengan jalan membuat semua tindakan dan perilaku konsisten dengan visi sudah dilakukan dengan baik untuk mendukung proses kepemimpinan mutu di Rumah Sakit Islam NU Demak.

Pertanyaan terkait apakah telah membangun visi di Rumah Sakit seluruh informan menjawab telah membuat visi dan misi di Rumah Sakit Islam NU Demak. Seperti yang diungkapkan oleh informan.

“....Ya kami membuat visi dan misi rumah sakit
melalui rapat dengan pihak direktur dan seluruh
direksi yang ada di rumah sakit...(A1)
“....Ya sudah ada mas....(B2)

Membangun visi sudah dilaksanakan untuk mendukung proses kepemimpinan mutu di Rumah Sakit Islam NU Demak. Dengan visi dan misi yang kuat serta terarah menyebabkan organisasi tersebut dapat melakukan perencanaan secara sistematis dan terpadu guna membangun kinerja yang lebih baik dan dapat terarah.

\section{Menggugah Proses di Rumah Sakit Islam NU Demak}

Terkait menggugah proses dengan membimbingan staf agar mereka mampu bekerja secara optimal menjalankan tugastugas pokoknya dijawab oleh informan bahwa proses membimbing staf melalui pengecekan setiap minggu di ruangan, komunikasi ketika rapat, evaluasi tiap 6 bulan sekali, pelatihan dan pendidikan serta masih banyak kegiatan lainnya untuk membimbing karyawan. Hal ini seperti yang diungkapkan oleh informan.

“.....Beberapa tindakan yan sudah kami kerjakan
mas diantaranya adalah pengecekan setiap minggu
ke ruangan-ruangan, komunikasi ketika rapat,
evalusasi tiap 6 bulan sekali, pelatihan dan
pendidikan serta masih banyak kegaiatan lainnya
untuk membimbing karyawan kami...(A2)
“.....Ya bimbingan melalui pelatihan sih ada
mas...setiap seminggu sekali ada pengawasan dari
manajemen di ruangan secara langsung....(B1)

Menggugah proses sudah dilaksanakan untuk mendukung proses kepemimpinan mutu di Rumah Sakit Islam NU Demak.

\section{Menggerakan Sumber Daya Manusia di Rumah Sakit Islam NU Demak}

Menggerakan sumber daya yaitu membangun jalinan komunikasi yang baik agar selalu tercipta kekompakkan dan 
bekerja dengan baik sudah dilaksanakan untuk mendukung proses kepemimpinan mutu di Rumah Sakit Islam NU Demak.

Seorang pemimpin yang mampu menggerakan para anggotanya haruslah punya keyakinan dan keberanian bahwa idenya itu bisa membawa manfaat bagi orang banyak. Selain itu, pemimpin yang mampu menggerakkan juga harus pandai dalam menghargai dan memahami anggotanya.

\section{Menjadi Model di Rumah Sakit Islam NU Demak}

Menjadi model dalam memberikan contoh perilaku disiplin sudah dilaksanakan untuk mendukung proses kepemimpinan mutu di Rumah Sakit Islam NU Demak. Pemimpin harus punya martabat, punya jati diri, punya filosofi yang dipertahankan, tidak mudah terpengaruh oleh rayuan-rayuan yang menggerogoti kredibilitasnya.

Seorang pemimpin harus kredibel dan memiliki pandangan jauh kedepan yang melampaui batas kekinian dan mampu mewujudkannya, mampu menciptakan calon penggantinya yang lebih baik dari pada dirinya dan setiap tidankannya dapat dijadikan contoh bagi anggota organisasi tersebut.

\section{PEMBAHASAN}

Tabel 1. Hasil Analisis dan Pembahasan dari Masing-Masing Variabel Penelitian

\begin{tabular}{lrlrr}
\hline \multicolumn{2}{c}{ Variabel dan Hasil } & \multicolumn{3}{c}{ Pembahasan } \\
\hline \multicolumn{1}{c}{ Peran, Fungsi dan Wewenang Governing Body } \\
\hline Peran & Governing & Body & Pelaksanaan & peran \\
sudah & dilaksanakan & Governing & Body & akan \\
untuk & mendukung & menjadi & yang \\
manajemen & mutu di & memperjuangkan & \\
Rumah Sakit Islam NU & kepentingan rumah sakit \\
Demak & & kepada pihak-pihak luar \\
& & termasuk & pemerintah, \\
& & sehingga rumah sakit benar- \\
& benar & mendapatkan \\
\hline
\end{tabular}

dukungan masyarakat dan bertanggung jawab terhadap kegiatan-kegiatan asuhan klinik terhadap pasien.

Fungsi Governing Body Fungsi Governing Body
sudah dilakukan untuk dalam proses mengangkat mendukung manajemen mutu di Rumah Sakit Islam NU Demak

direksi, perencanaan, penganggaran, pengangkatan karyawan dan pengawasan keuangan sudah sesuai dengan tujuan peningkatan manajemen mutu di Rumah Sakit Islam NU Demak

\begin{tabular}{lrl}
\hline Wewenang & Governing & Perlu diperbaiki dalam hal: \\
Body & belum & Perencanaan peningkatan \\
dilaksanakan & secara & kompetensi melalui pelatihan \\
optimal & untuk & untuk petugas medis dan \\
mendukung & manajemen & perawat
\end{tabular}
mutu di Rumah Sakit Islam NU Demak

\begin{tabular}{lrlr}
\hline \multicolumn{4}{l}{ Peran, Fungsi dan Wewenang Direktur } \\
\hline Peran Direktur & sudah & Peran direktur yang sudah \\
dilaksanakan & untuk & dilakukan yaitu membuat \\
mendukung manajemen & tujuan rumah r sakit, \\
mutu di Rumah Sakit & menjalankan $\quad$ kebijakan, \\
Islam NU Demak & SPO, menyusun rencana \\
& kerja dan anggaran, \\
& koordinasi pelaksanaan tugas \\
& dan fungsi melakukan \\
& pembinaan, pengawasan, dan \\
& pengendalian r sudah \\
& dilakukan sesuai harapan \\
& untuk mendukung dari \\
& proses peningkatan \\
& manajemen mutu.
\end{tabular}
Fungsi Direktur belum Masih ada yang perlu dilaksanakan secara perbaikan yaitu Pedoman optimal untuk sistem pencatatan, pelaporan mendukung manajemen mutu di Rumah Sakit Islam NU Demak

\begin{tabular}{lrlr}
\hline Wewenang & $\begin{array}{r}\text { Direktur } \\
\text { sudah }\end{array}$ & Wewenang direktur meliputi \\
untuk & mendukung & operasional, menetapkan \\
manajemen mutu di & peraturan, mengusulkan \\
Rumah Sakit Islam NU & rencana kerja, anggaran, \\
Demak & pengembangan, \\
& pengendalian, \\
& penyelenggaraan rumah sakit \\
& agar tercapai target sudah \\
& dilakukan dengan baik sesuai \\
& dengan harapan untuk \\
& mendukung dari manajemen \\
& mutu yang ada di Rumah \\
& Sakit Islam NU Demak.
\end{tabular}

Peran, Fungsi dan Wewenang Komite Medik

Peran Komite Medik Peran komite medik meliputi 


\begin{tabular}{|c|c|}
\hline $\begin{array}{lr}\text { sudah } & \text { dilaksanakan } \\
\text { untuk } & \text { mendukung } \\
\text { manajemen mutu di } \\
\text { Rumah Sakit } & \text { Islam NU } \\
\text { Demak } & \end{array}$ & $\begin{array}{l}\text { cara menyelenggara tata } \\
\text { kelola klinis (clinical } \\
\text { governance) yang baik dan } \\
\text { proses menjaga } \\
\text { profesionalisme staf medis } \\
\text { serta pemiliharaan etika dan } \\
\text { disiplin profesi sudah } \\
\text { dllakukan sesuai dengan } \\
\text { harapan untuk meningkatkan } \\
\text { manajemen mutu di Rumah } \\
\text { Sakit Islam NU Demak. }\end{array}$ \\
\hline $\begin{array}{lr}\text { Fungsi } & \text { Komite } \\
\text { sudah } & \text { Medik } \\
\text { untuk } & \text { mendukung } \\
\text { manajemen mutu di } \\
\text { Rumah } \\
\text { Demakit }\end{array}$ & $\begin{array}{l}\text { Fungsi komite medik dalam } \\
\text { proses kredensial sudah } \\
\text { dilakukan sesuai dengan } \\
\text { harapan untuk meningkatkan } \\
\text { manajemen mutu di Rumah } \\
\text { Sakit Islam NU Demak. }\end{array}$ \\
\hline $\begin{array}{lr}\text { Wewenang } & \text { Komite } \\
\text { Medik } & \text { belum } \\
\text { dilaksanakan } & \text { secara } \\
\text { optimal } & \text { untuk } \\
\text { mendukung } & \text { manajemen } \\
\text { mutu di Rumah } & \text { Sakit } \\
\text { Islam NU Demak } & \end{array}$ & $\begin{array}{l}\text { Perlu diperbaiki } \text { dalam } \\
\text { beberapa hal: menambah } \\
\text { tenaga dokter spesialis, } \\
\text { membentuk tim kerja, } \\
\text { memberikan pelatihan atau } \\
\text { mengikuti pelatihan di } \\
\text { tempat lain untuk } \\
\text { meningkatkan keterampilan } \\
\text { tenag medis dan perencanaan } \\
\text { mengenai peningkatan } \\
\text { pendidikan dokter spesialis }\end{array}$ \\
\hline \multicolumn{2}{|c|}{ Peran, Fungsi dan Wewenang Komite Keperawatan } \\
\hline $\begin{array}{lr}\text { Peran } & \text { Komite } \\
\text { Keperawatan } & \text { belum } \\
\text { dilaksanakan } & \text { secara } \\
\text { optimal } & \text { untuk } \\
\text { mendukung manajemen } \\
\text { mutu di Rumah } & \text { Sakit } \\
\text { Islam NU Demak } & \end{array}$ & $\begin{array}{l}\text { Perlu diperbaiki dalam hal: } \\
\text { belum dilakukan } \\
\text { penyelenggara tata kelola } \\
\text { keperawatan yang baik dan } \\
\text { memberikan pelatihan atau } \\
\text { mengikuti pelatihan di } \\
\text { tempat lain untuk } \\
\text { meningkatkan keterampilan } \\
\text { tenaga perawat }\end{array}$ \\
\hline $\begin{array}{lr}\text { Fungsi } & \begin{array}{r}\text { Komite } \\
\text { Keperawatan }\end{array} \\
\text { dilaksanakan } & \text { secara } \\
\text { optimal } & \text { untuk } \\
\text { mendukung manajemen } \\
\text { mutu di Rumah } & \text { Sakit } \\
\text { Islam NU Demak } & \end{array}$ & $\begin{array}{l}\text { Perlu diperbaiki } \\
\text { beberapa halam } \\
\text { perencanaan belum ada } \\
\text { kredensial dan rekredensial } \\
\text { untuk tenaga keperawatan } \\
\text { dan belum dilakukan } \\
\text { pemeliharaan mutu profesi } \\
\text { dan belum dilakukan proses } \\
\text { menjaga disiplin, etik dan } \\
\text { perilaku }\end{array}$ \\
\hline $\begin{array}{lr}\text { Wewenang } & \text { Komite } \\
\text { Keperawatan } & \text { sudah } \\
\text { dilaksanakan } & \text { untuk } \\
\text { mendukung } & \text { manajemen } \\
\text { mutu di Rumah } & \text { Sakit } \\
\text { Islam NU Demak } & \end{array}$ & $\begin{array}{lr}\text { Wewenang } & \text { komite } \\
\text { keperawatan } & \text { dalam } \\
\text { memberikan } & \text { rekomendasi } \\
\text { rincian } & \text { kewenangan } \\
\text { keperawatan } & \text { sudah } \\
\text { dilakukan dengan baik sesuai } \\
\text { dengan harapan untuk } \\
\text { mendukung dari manajemen } \\
\text { mutu yang ada di }\end{array}$ \\
\hline
\end{tabular}

Sakit Islam NU Demak

Pelaksanaan Manajemen Mutu

Perencanaan Mutu sudah dilaksanakan mendukung dari manajemen mutu yang ada di Rumah Sakit Islam NU Demak

Perencanaan mutu yang

meliputi cara pemenuhan

kebutuhan

pelanggan/konsumen,

menentukan market segment

pelayanan, proses mengembangkan

karakteristik pelayanan dan cara mengembangkan pelayanan sudah berjalan baik untuk mendukung dari manajemen mutu yang ada di Rumah Sakit Islam NU Demak.

Pengendalian Mutu Beberapa hal yang perlu belum dilaksanakan diperbaiki yaitu Bagian secara optimal komite keperawatan belum mendukung manajemen memiliki pedoman bila mutu di Rumah Sakit terjadi perbedaan antara Islam NU Demak performa aktual dengan target dan belum ada pedoman terkait dengan pelatihan untuk meningkatkan keterampilan tenaga yang ada di Rumah Sakit Islam NU Demak.

Peningkatan Mutu belum Beberapa hal yang perlu dilaksanakan secara diperbaiki yaitu belum ada optimal untuk pedoman untuk membentuk mendukung manajemen tim kerja dan pengembangan mutu di Rumah Sakit sarana dan prasarana belum Islam NU Demak sesuai dengan kebutuhan dan standar karena keterbatasan dana dan belum ada pedoman yang mengatur pengadaan sarana dan prasarana di Rumah Sakit Islam NU Demak.

Pelaksanaan Kepemimpinan Mutu

Membangun Visi sudah Membangun visi yang
dilaksanakan untuk dilakukan meliputi membuat mendukung proses visi, mengkomunikasikan, kepemimpinan mutu di membangun jejaring dan Rumah Sakit Islam NU mempersonafikasikan visi Demak dengan jalan membuat semua tindakan dan perilaku konsisten dengan visi sudah dilakukan dengan baik untuk mendukung proses kepemimpinan mutu di Rumah Sakit Islam NU Demak

\begin{tabular}{lllr}
\hline Menggugah Proses sudah & Menggugah proses & meliputi \\
dilaksanakan mendukung & proses bimbingan & kepada \\
proses kepemimpinan & staff agar mereka mampu \\
\hline
\end{tabular}




\begin{tabular}{lrlr}
\hline mutu di Rumah Sakit & bekerja secara optimal \\
Islam NU Demak & & menjalankan tugas-tugas \\
& & pokoknya sesuai dengan \\
& ketrampilan yang telah \\
& dimiliki dan dukungan \\
& & sumber daya yang tersedia \\
& & sudah dilakukan dengan baik \\
& & untuk mendukung proses \\
& & kepemimpinan mutu di \\
& & Rumah Sakit Islam NU \\
Menggerakan & Sumber & Menggerakan sumber daya \\
Daya Manusia & sudah & manusia yaitu membangun \\
dilaksanakan & untuk & jalinan komunikasi yang \\
mendukung & proses & baik agar selalu tercipta
\end{tabular}

\section{KESIMPULAN}

Peran, dan fungsi Governing Body sudah dilaksanakan namun wewenang Governing Body belum dilaksanakan secara optimal dengan perbaikan pada perencanaan peningkatan kompetensi melalui pelatihan untuk petugas medis dan perawat.

Direktur belum menjalankan fungsinya secara optimal dan perlu membuat pedoman sistem pencatatan dan pelaporan yang jelas. Sedangkan komite medik diketahui belum melaksanakan wewenang secara optimal dan perlu merencanakan pengadaan spesialis, peningkatan keterampilan dan pendidikan tenaga dokter spesialis. Pada komite keperawatan ditemukan belum melaksanakan peran dan fungsinya secara optimal dan perlu perbaikan dalam tata kelola, peningkatan kompetensi perawat serta perencanan proses kredensial dan rekredensial untuk tenaga keperawatan.

Proses membangun visi, menggungah proses, menggerakkan sumber daya, dan menjadi model sudah dilaksanakan untuk mendukung proses kepemimpinan mutu yang ada di Rumah Sakit Islam NU Demak

\begin{tabular}{|c|c|}
\hline kepemimpinan mutu di & kekompakkan dan bekerja \\
\hline Rumah Sakit Islam NU & dengan ba1k sudah dilakukan \\
\hline Demak. & dengan baik untuk \\
\hline & menaukung \\
\hline & kepemimpinan \\
\hline & Rumah Sakit \\
\hline & Demak \\
\hline $\begin{array}{ll}\text { Menjadi Model } & \text { sudah } \\
\text { dilaksanakan } & \text { untuk }\end{array}$ & $\begin{array}{l}\text { Menjadi model dalam } \\
\text { memberikan contoh perilaku }\end{array}$ \\
\hline mendukung & disiplin sudah dilakukan \\
\hline kepemimpinan mutu di & dengan \\
\hline Rumah Sakit Islam NU & mendukung \\
\hline Demak. & kepemimpinan \\
\hline & Rumah \\
\hline & Demak \\
\hline
\end{tabular}

\section{DAFTAR PUSTAKA}

1 Jacobalis, S. Merancang Hospital Bylaws Indonesia, Rakernas PERSI, Denpasar; 2002.

2 Keputusan Menteri Kesehaatan Republik Indonesia. No. 772/MENKES/ SK/ VI/ 2002, Tentang Pedoman Peraturan Internal Rumah Sakit (Hospital Bylaws)

3 Keputusan Menteri Kesehatan. No. 631/MENKES/SK/IV/2005 tentang Pedoman Peraturan internal Staf Medis (Medical Staff bylaws) di rumah sakit

4 Cyril O. Houle, Governing Board, Jossey-Bass Publishers, San Francisco; 1997

5 Undang-Undang Nomor. 44 tahun 2009 tentang Rumah Sakit,

6 Peraturan Menteri Kesehatan Republik Indonesia Nomor 10 Tahun 2014 Tentang Dewan Pengawas Rumah Sakit

7 Undang-undang Nomor. 40 Tahun 2007 tentang Perseroan Terbatas

8 Peraturan Presiden Republik Indonesia Nomor 77 Tahun 2015 Tentang Pedoman Organisasi Rumah Sakit

9 J. Guwandi. Hospital Law (Emerging doctrines and Jurisprudence). Jakarta: FKUI; 2005 
10 Sulastomo. Manajemen Kesehatan. Jakarta: Penerbit Gramedia Pustaka Utama; 2003.

11 Peraturan Menteri Kesehatan Republik Indonesia Nomor 755/MENKES/PER/IV/2011 Tentang Penyelenggaraan Komite Medik Di Rumah Sakit

12 Peraturan Menteri Kesehatan No 49 tahun 2013 tentang Komite Keperawatan

13 Juran, JM. Merancang Mutu, Buku ke 2, Seri Manajemen 164B. Jakarta: Pustaka Binaman Pressindo; 1996

14 Nasution, M. N. Manajemen Mutu Terpadu (Total Quality Manajement), Edisi kedua. Bogor: Graha Indonesia; 2005

15 Juran, JM. Kepemimpinan. Pedoman Peningkatan Mutu untuk Meraih Keunggulan Kompetitif. Jakarta: Pustaka Binaman Pressindo; 1995

16 Azrul Azwar. Standar dalam Program Menjaga Mutu. MKMI; 1993

17 Dep. Kes. RI. Modul Pelatihan Rumah Sakit, Mutu Pelayanan. Depkes. Jakarta; 2008

18 Amirullah, H. Pengantar Manajemen. Graha Ilmu, Yogyakarta, 2004

19 Munro Faure, L dan Munro Faure, M, Implementing Total Quality mananagement Menerapkan Manjemen Mutu Terpadu, Times Management series, British Institute of management, 1997.

20 Tjiptono, F dan Diana, A. Total Quality Management, edisi revisi, Andi, Yogyakarta, 2003, hal 4-172

21 Nasution, M. N. Manajemen Mutu Terpadu (Total Management Quality), Edisi kedua, Graha Indonesia, Bogor, 2005.

22 Gaucher, E.J, Coffey, R. J. Total
Quality in Healthcare, From Theory till practice, Jossey-Bass Publisher, San Francisco, 1993

23 Manus, Burt, Kepemimpinan Visioner, Menciptakan Kesadaran Akan Arah dan Tujuan dalam Organisasi, Alih Bahasa, Frederik Ruma, PT Prenhalindo, Jakarta, 2001

24 Ulrich, Dave, Leadership in AsiaChallenges and Opportunities, The MsGraw-Hill Cmpanies, 2010

25 Moleong, Lexy J. Metode Penelitian Kualitatif. Bandung : Remaja Rosda Karya; 2006

26 Arikunto S. Prosedur Penelitian Suatu Pendekatan Praktik. Jakarta: PT Rineka Cipta; 2010

27 Notoadmodjo, S. Metodologi Penelitian Kesehatan. Cetakan Pertama. Jakarta : PT. Rineka Cipta; 2010 